\title{
True Triaxial Piping Test Apparatus for Evaluation of Piping Potential in Earth Structures
}

\author{
Kevin S. Richards \\ Graduate Research Assistant, Department of Civil and Materials Engineering, University of \\ Illinois at Chicago, 842 West Taylor Street, Chicago, Illinois 60607, USA, \\ e-mail: kevinlaurie@sbcglobal.net
}

\section{Krishna R. Reddy}

Professor, Department of Civil and Materials Engineering, University of Illinois at Chicago, 842 West Taylor Street, Chicago, Illinois 60607, USA, e-mail: kreddy@uic.edu

\section{Final Manuscript Submitted to:}

Geotechnical Testing Journal, ASTM 


\title{
True Triaxial Apparatus Piping Test Apparatus for Evaluation of Piping Potential in Earthen Structures
}

\begin{abstract}
Current methods available for testing the piping potential of soils in dams (pinhole test, hole erosion test, slot erosion test) are limited to cohesive soils that maintain an open hole within the sample. These tests do not adequately simulate conditions within a zoned embankment, where zones of noncohesive materials are present under relatively high confining stresses. A new apparatus, called true triaxial piping test apparatus or TTPTA, was developed for testing a wider variety of soils under a wider range of confining stresses, hydraulic gradients, and pore pressures than current tests allow. The TTPTA is capable of applying a range of confining stresses along three mutually perpendicular axes in a true-triaxial test apparatus. Pore pressures are also controlled through regulated inlet and outlet pressures. The test determines the critical hydraulic gradient and, more importantly, the critical hydraulic velocity at which piping is initiated in non-cohesive soils. Detailed descriptions of the test apparatus and test method are presented, as are initial test results using TTPTA. Three sets of initial tests were conducted using uniform sand to (1) assess the repeatability of test results, (2) evaluate how the rate of change of in-flow impacts the critical dischare rate at which piping is initiated, and (3) evaluate how the angle of seepage affects the critical velocity for piping initiation These initial tests were conducted to evaluate the method and to help set test parameters for future testing. It is found that the TTPTA is capable of yielding fairly consistent results with $10 \%$ scatter in repeat tests. The seepage angle tests demonstrate that the angle between seepage flow direction and the direction of gravity is an important factor to consider when evaluating piping potential. The rate of change in seepage also has a minor influence on test results, but a change in flow rate of 5
\end{abstract}


$(\mathrm{ml} / \mathrm{min}) / \mathrm{min}$ could produce reliable results. Based on the results, the hydraulic gradient is found to be a less reliable indicator of piping potential than the hydraulic velocity for noncohesive soils. The TTPTA is capable of simulating conditions within small to medium sized embankments.

KEYWORDS: piping potential, piping tests, critical hydraulic gradient, critical hydraulic velocity, true triaxial piping test

\section{INTRODUCTION}

Numerous earth structures, particularly earth dams, commonly fail by piping. In fact, approximately half of all dam failures are due to piping (Foster, Fell, and Spangle, 2000), with approximately $33 \%$ of all piping failures possibly attributed to backwards erosion piping (Richards and Reddy, 2007). Different modes of piping failure have been recognized in the literature and are defined by the mechanism causing the piping. The modes commonly recognized include backwards erosion, internal erosion, tunneling, suffusion, and heave (Richards and Reddy, 2007). In order to evaluate piping potential in earthen dams, the first standardized laboratory piping tests were developed in the 1970's; commonly known as the pinhole test, ASTM D4647-93, and the double hydrometer test, ASTM D4221-99 (Sherard et al., 1976, Decker and Dunnigan, 1977). The tests were originally developed to assess piping potential due to the dispersivity of soils. Dispersive soils are highly prone to piping failure (Aitchison, et al., 1963) and these tests were specifically developed to evaluate a soil's piping potential in areas with dispersive soils. Prior to these early laboratory tests, empirical methods were available to assess piping potential. Bligh (1910) recommended percolation factors for 
various types of non-cohesive soils based on empirical data. Bligh's method was later improved by the work of Lane (1934). These empirical methods have a significant shortcoming; they are based on seepage flow paths consistent with internal erosion and do not adequately address the potential for backwards erosion. Terzaghi (1922) developed the classic theory of heave, which is based on theoretical application of soil mechanics. This theory is commonly used to evaluate piping potential. However, Terzaghi's theory does not consider the physico-chemical or other properties of soils that influence piping potential. It was originally based on the case where seepage flow is vertically upward into a cofferdam, acting in direct opposition to the downward force of gravity. Does this theory apply equally to the case with seepage exiting at a downward angle on the downstream slope of an embankment dam? No standardized laboratory tests have been developed to assess piping potential in non-cohesive soils that could be used to evaluate piping potential in a way that would take all these other factors into account.

Some new tests were recently developed to study erosion potential of cracks in embankment dams. The Hole Erosion Test (HET) and Slot Erosion Test (SET) were developed for this purpose in 2004 (Wan and Fell, 2002, 2004). These tests are designed to assess the erosion rate index of soils subjected to concentrated leaks, for research into the rate of erosion for breach analyses and also have application in risk assessments. However, the HET and SET may not be directly applicable to cases of backwards erosion piping since the mode of piping being evaluated in these tests is interior erosion. A number of other tests have been developed to assess surficial erosion, such as occurs in cases of overtopping failures of embankment dams or around bridge abutments; however, these also are not directly applicable to backwards erosion 
piping. These include the jet erosion and rotating cylinder tests (Moore and Masch, 1962) and the erosion function apparatus (EFA) (Briaud et al., 2001).

This paper first provides a critical review of current piping test methods, and then describes the development of true triaxial piping test apparatus and the sample preparation and testing. Finally, a series of experimental results are presented to investigate reproducibility of the test results and the effects of rate of in-flow and angle of seepage on piping initiation.

\section{CURRENT PIPING TEST METHODS}

The pinhole test (ASTM D4647-93) was developed by Sherard et al. (1976) to assess the presence of dispersive clay in soils, which is known to increase the risk of piping in embankment dams (Aitchison et al., 1963). The test is not applicable to soils with less than $12 \%$ fraction finer than $0.005 \mathrm{~mm}$ and with a plasticity index less than or equal to 4 . The test consists of a tube sealed at both ends with steel or aluminum plates and o-rings. Gravel drains are placed at either end of the tube with a 1.5 inch long section of compacted soil sandwiched between the drains. A manometer or other device controls the inlet pressure at one end of the cylinder; the other end is open to atmospheric pressure. The test is conducted with the cylinder in the horizontal position. Water is allowed to flow through the sample for anywhere from 5 to 10 minutes under each head condition. To facilitate the erosion process, a $1.0 \mathrm{~mm}$ pinhole is punched through the center of the compacted soil. The test is conducted by gradually increasing the inlet pressure from 2-inch (50-mm), to 7 -inch (180-mm), to 15 -inch (380-mm), to 40-inch (1020-mm) head. The discharge rate is measured and visually inspected for clarity. The test is conducted until the clarity of the discharge and flow rate indicate that piping has progressed. The soil is rated into one of five 
categories, based on the head at which the piping commenced, the amount of sediment in the discharge (based on visual estimate of clarity) and the size of the eroded hole after the test.

A recent advancement was the development of the HET and SET tests, developed by Wan and Fell (2002). These tests were not specifically developed to assess soils for their backwards piping characteristics. The HET and SET tests were designed to determine the erosion rate in soils subject to concentrated leaks, such as might occur in a crack through cohesive soils in the core of a dam. The HET consists of compacting soil in a standard mold used for the compaction test. A 6-mm hole is drilled through the sample and an increasing hydraulic head applied across the sample with a constant $100 \mathrm{~mm}$ of water column applied at the outlet end of the sample. The test is done horizontally and is quite similar to the pinhole test, except for the dimensions of the apparatus and the hole diameter. The evaluation of the test is done differently than the pinhole test in that the hole diameter is computed from the flow rate rather than direct measurement. The SET is similar to the HET with respect to evaluation of the data and computation of an erosion rate index, but the apparatus is a rectangular box $0.15 \mathrm{~m}$ wide, $0.1 \mathrm{~m}$ deep, and $1 \mathrm{~m}$ long. A slot is formed into the top of the soil, which is compacted into the box. In both the HET and SET, erosion occurs in a preformed pipe, similar to the pinhole test.

Other tests, which may have application to suffusion and backwards erosion piping have been reported in the literature. These tests were developed by a number of researchers (Valdes and Liang, 2006; Kakuturu, 2003; Tomlinson and Vaid, 2000; Skempton and Brogan, 1994; Bertram, 1940) to evaluate various modes of piping behavior of soils. For example, Kakuturu, 2003 developed tests and a method for prediction of the healing that occurs by self filtration. 
Skempton and Brogan, 1994 provided a method for evaluation of soils prone to suffusion (a profound lack of self filtration). Valdes and Liang, 2006 and Bertram, 1940 evaluated the performance of engineered filters. Tomlinson and Vaid, 2000 developed a test to evaluate the effect of uniaxial stress on piping. Their test consisted of a uniaxially loaded sample of soil placed in a vertical cylinder $10-\mathrm{cm}$ in diameter and $10-\mathrm{cm}$ long. There is a gravel drain (specifically designed to allow passage of sediments) at the bottom of the cylinder with a $1.5 \mathrm{~mm}$ mesh at the bottom. Soil piped through the coarse filter is allowed to collect in a pan at the base of the apparatus. The soil is placed on top of the gravel drain with a $1.5 \mathrm{~mm}$ mesh at the top of the soil. Fluid is introduced in the top of the cylinder through holes drilled into a platen that applies a vertical load to the sample. The hydraulic head on the outlet side of the apparatus is controlled by submerging it in a large water bath with constant water level maintained. Hydraulic head to the inlet side is controlled by throttling a valve open to the water supply system line pressure. The maximum differential head achieved with this system is $100 \mathrm{~cm}$ of water. Flow rate was monitored by measuring the flow out of the water bath. The amount of sediment in the fluid discharge is used to assess migration (piping) of particles. This test is unique in that it tests piping in a vertically oriented downward direction. They found that the confining pressure, and the magnitude and rate of gradient increase may influence initiation of piping. Skempton and Brogan (1994) used a similar device but with flow being oriented vertically upward, to test piping potential in gap-graded soils. They were also interested in comparison of similar tests of internally unstable soils conducted on horizontally oriented samples (Adel et al., 1988). These tests were used to assess the internal stability of gap graded soils. 
The pinhole test is a difficult test to run and is prone to premature clogging or self-healing of the pinhole. It works best in soils that can maintain an open pinhole under conditions of flow; hence, it works best in soils with cohesion and little self healing properties. The test is good for discerning dispersive from non-dispersive soils that meet these requirements, but it does not yield an erosion index or other parameters that might be useful for comparison between nondispersive soils of wider gradations. The test is only applicable to internal erosion, erosion along concentrated leaks through pre-existing openings, and does not provide evaluation of backwards erosion piping potential. The hole and slot erosion tests are designed to yield specific erosion parameters, such as the erosion rate index, that can be used to assess the erodibility and rate of erosion of non-dispersive soils subjected to concentrated leaks through pre-existing openings. However, the hole erosion test is limited to cohesive soils that maintain an open hole under flow conditions. Since the diameter of the hole is greater than in the pinhole test, it is less prone to self healing or clogging. The slot erosion test can be used for soils with a wider range of cohesion, but due to the proximity of the slot against the top of the cell, may be more indicative of internal erosion potential (erosion along a soil-structure contact).

Other tests discussed in the literature have similar limitations with respect to backwards erosion potential in non-cohesive soils. For example, some are limited to testing suffusion or heave (Skempton and Brogan, 1994), and others are limited to testing internal erosion (Adel et al., 1988). Tomlinson and Vaid, 2000, presented a test that may have some application to backwards erosion potential. However, the geometry of the apparatus is limited to vertically downward flow and therefore does not provide an adequate analog to backwards erosion piping in dams. 
In light of the drawbacks with current methods for testing piping in non-cohesive soils, a new instrument was developed that could test a wider range of soils. The new instrument allows for testing piping characteristics of soils within a range of hydraulic conditions and confining stresses. An important difference between this new test and currently available tests is that the new test is specifically designed to evaluate backwards erosion piping potential rather than erosion along a pre-existing opening (internal erosion).

\section{TRUE TRIAXIAL PIPING TEST APPARATUS (TTPTA)}

\section{General System Description and Diagram}

The TTPTA was developed to permit testing a wider range of soil types, particularly noncohesive soils, for backwards-erosion piping potential under variable confining pressure conditions. The TTPTA was perfected after two earlier prototypes were tested and improvements made to the overall design and instrumentation. The apparatus is capable of simulating conditions within a small to medium sized zoned embankment dam. The apparatus provids the critical hydraulic gradient and the critical hydraulic velocity required to initiate piping, while recording such variables as the inlet flow rate, inlet and outlet pressure heads, mass

of discharged effluent per second, and differential pressure every 100 milliseconds. The apparatus is constructed around a true-triaxial load cell capable of initiating backwards erosion type piping under variable pore and confining pressures. The complete apparatus consists of an Inlet-Outlet Pressure Control Panel, an Inlet-flow Control Panel, the True Triaxial Load Cell, an Outlet Tube, Inlet/Outlet Valve Trees, a Flow-Through Turbidimeter, and Pressurized Water Source and Pressurized Receiving Vessels, and the Instrumentation and Data Logging 
Equipment. A photograph of the True Triaxial test cell, which is the heart of the system, is shown in Figure 1 and a diagram of the overall system is shown in Figure 2.

\section{Inlet-Outlet Pressure Control Panel}

The purpose of the Inlet-Outlet Pressure Control Panel is to provide finely regulated air pressures to the Pressurized Water Source, and Receiving Vessels. The panel is connected to a standard air compressor/storage tank capable of supplying $100 \mathrm{psi}(689 \mathrm{kPa})$ compressed air. The air pressure supplied through the control panel to the source and receiving vessels is regulated with air regulators capable of supplying constant air pressure from 0 to $15 \mathrm{psi}$ ( 0 to $103 \mathrm{kPa})$. It also is used to create and supply a vacuum to the True Triaxial Load Cell prior to saturating a loaded sample. The vacuum is also used to evacuate the Pressurized Water Source Vessel the night before tests are run. This is done to ensure air is removed from the source water before running the test. The Inlet-Outlet Pressure Control Panel vacuum generator is capable of creating a -8.7 psi $(-60 \mathrm{kPa})$ vacuum. A water trap and a $0-90 \mathrm{psi}(0-620 \mathrm{kPa})$ pressure regulator that supplies air pressure to the Air Bladder Control Panel are also included on the panel, as are the various tubing and quick release connectors required to connect all the equipment. A diagram of the Inlet-Outlet Pressure Control Panel is shown in Figure 3, and a photograph of the Inlet-Outlet Pressure Control Panel in Figure 4a.

\section{Inlet-flow Control Panel}

The Inlet-flow Control Panel (Figure 4b and Figure 5) conveys water from the Pressurized Water Source Vessel to the True-Triaxial Load Cell through either a high-volume flow gage, or a lowvolume flow gage, depending on what the sample requires. There is also a granular filter to 
further remove any entrained air (Bertram, 1940). A water filter is also used to remove any sediment or other impurities in the water. The inlet-flow control panel is also equipped with three-way valves for switching between the high and low flow gages, and for switching to gage or bypass mode. The bypass mode allows tapping into the Pressurized Water Source when deaired water is needed during the soil saturation procedure.

\section{True-Triaxial Load Cell System}

Several components make up the true-triaxial load cell system. There is the outer case, which makes up the load cell. Inside the load cell are three air bladder pistons, which provide the confining stresses to the soil sample along three orthogonal directions. The stresses applied by each of these air bladder pistons can be independently controlled; hence, it is a true-triaxial load cell.

\section{Triaxial Load Cell Components}

The outer case of the Load Cell also serves as the reaction frame. It is composed of 1-inch (25 $\mathrm{mm}$ ) thick aluminum or Lexan plate. The outer case is held together with a flexible adhesive to seal the contacts (except along the bottom plate), and $1 / 4$ inch $(6.3 \mathrm{~mm})$ diameter stainless steel bolts. A rubber gasket is used along the bottom plate to allow its removal for loading the cell. A $1 / 4$ inch $(6.3 \mathrm{~mm})$ hole is at one end of the top plate to provide an inlet for water, and a $1 / 2$ inch $(12.7 \mathrm{~mm})$ hole is provided at the downstream end plate to provide an outlet. This outlet hole is located near the bottom of the load cell and has a recessed flange for fitting a $1 / 2$ inch $(12.7 \mathrm{~mm})$ diameter washer with an inside-hole sized for the outside diameter of the outlet pipe. The washer is attached to the pressure vessel with a flexible adhesive and when in-place should be 
flush with the inside face of the load cell. The outlet pipe should easily slide into the washer with minimal space between the outside of the outlet pipe and inside of the washer. The end of the outlet pipe should fit flush with the inside face of the pressure vessel. Three sides of the pressure vessel have threaded $1 / 4$ inch $(6.4 \mathrm{~mm})$ holes to provide inlets for compressed air, which fills the Air Bladder Pistons located inside the pressure vessel. The holes are fully penetrating and are threaded on both sides. These three holes are located along the primary axes of the soil sample and will provide the $\sigma 1, \sigma 2$, and $\sigma 3$ stresses to the soil. The holes are offset to allow some space for the bladders to inflate without interfering with each other. One of the bladders is located at the top of the cell so that when inflated, it will help fill any voids between the cell wall and soil due to minute settlement of the soil. The bottom piece also has a neoprene pad that also helps to prevent voids from forming by applying some pressure to the soil when the cover is put on after loading the sample. Finally, there are grooves cut on the inside walls of the left and right sides of the pressure vessel. The grooves allow a steel or aluminum plate to be temporarily inserted prior to filling the vessel with gravel drain materials and the soil sample. The plate supports the gravel drain and screen prior to placing soil into the pressure vessel. Two other $1 / 4$ inch $(6.4 \mathrm{~mm})$ diameter threaded holes are provided for monitoring the internal pore pressure at the outlet and for monitoring differential pressure across the load cell.

\section{Air Bladder Control Panel}

Figure $4 \mathrm{c}$ shows the Air Bladder Control Panel. The air bladders are typically guaranteed to a maximum fill pressure that must not be exceeded during the test. This maximum pressure is the limiting factor in the magnitude of loads and pore pressures that can be evaluated under this test. The compressed air that is supplied by the Inlet-Outlet Pressure Control Panel is conveyed to a 
manifold within the Air Bladder Control Panel. The manifold provides a three-way split of the supplied air to three pressure regulators and equipped with glycerin-filled stainless steel gauges. The air bladders used in this research were guaranteed to a maximum 30-psi internal pressure; hence, the pressure regulators and gages in the Air Bladder Control Panel were designed for an operating range of 0 to $30 \mathrm{psi}(0$ to $207 \mathrm{kPa})$, which is adequate for simulating internal stresses within small embankments or levees. The air regulators and gages could be changed if higher pressure air bladders are used in the Air Bladder Pistons for evaluations of conditions within larger embankments.

\section{Air Bladder Piston}

The soil sample is subjected to stress by steel plates driven by air bladders. The steel plates and air bladders are enclosed in a flexible membrane to prevent seepage from bypassing the soil sample. The arrangement of a top and bottom steel plate sandwiching an air bladder, all enclosed in a latex cover, is what makes up an air bladder piston. A standard 4-inch (100 mm) triaxial membrane, 0.012 inches $(0.3 \mathrm{~mm})$ thick and 12 inches $(305 \mathrm{~mm})$ long will serve this purpose. The piston components are assembled and inserted into the membrane sleeve. The two ends of the sleeve are glued and folded onto the bottom of the piston and attached to the inside wall of the Pressure Vessel with a flexible adhesive. The air bladders are equipped with male NPT fittings for air inlet that screw into the load cell wall. Neoprene pads are also provided on the steel plates that make contact with the soil to accommodate any small voids or bumps that may be present at the soil/piston surface and to help form a seal between the pistons and soil. The air bladders can be acquired from companies specializing in fabrication of custom air bladders, commonly used for lifting large heavy objects. There are a variety of materials that can 
be used to fabricate the air bladders depending on the amount of pressure that will be contained within the bladder. Higher pressure air bladders are generally more expensive. The dimensions and cross sectional view of the Air Bladder Piston (air bladders, steel plates, neoprene pads, and latex sleeve) are shown in Figure 6.

\section{Outlet Tube}

The outlet pipe is a thin walled aluminum pipe cut to length to fit into the apparatus.

For these tests, an ultra-corrosion resistant aluminum tube with $0.319 \mathrm{inch}(8.1 \mathrm{~mm})$ inside diameter and 0.028 inch $(0.7 \mathrm{~mm})$ wall thickness used. This diameter was selected as approximately the smallest diameter pipe that would yield unimpeded piping for medium sized granular materials. A smaller diameter outlet pipe may lead to bridging at the outlet for medium sand soils and would also be difficult to equip with the Light Emitting Diode in the FlowThrough Turbidimeter (discussed in a following section). A small diameter outlet was selected since it will provide a critical hydraulic velocity to initiate piping in the smallest soil-pipe possible within the test limitations, and would therefore provide a closer approximation of the true critical velocity required to initiate a soil-pipe within the embankment. Another size of outlet pipe could be used depending on the gradation of soil particles being tested.

\section{Inlet/Outlet Valve Trees}

A diagram of the inlet and outlet valve trees is shown in Figure 7. There are three requirements to run this test; 1) evacuating air from the loaded soil before saturating the sample, 2) flushing air from the differential pressure gage monitoring lines, and, 3) after setting desired pore pressure, equalizing the pressure inside the load cell with the pressure in the outlet valve tree. The 
pressures must be equalized prior to allowing water to flow through the apparatus or the test will fail. The inlet/outlet valve trees serves these purposes. The inlet valve tree consists of two ball valves at either end of a T-connection. The inlet valves allow isolating the load cell from the inlet source, and for isolating the inlet pressure transducer from the load cell and inlet source, if needed. However, the more important valve tree is the outlet valve tree. The outlet valve tree also consists of two ball valves at either end of a T-connection. The valves allow flushing water through the inlet monitoring line (which is attached to the T) without disturbing the sample and for isolating the load cell from the outlet tree until the internal and external pressures are equalized. A pressure transducer is used in the inlet valve tree to monitor inlet pressures. The flow-through turbidimeter is attached to the upstream end of the outlet valve tree.

\section{Flow-Through Turbidimeter}

A flow through turbidimeter monitors the clarity of water at the outlet end of the load cell. The turbidimeter consists of an infrared detector, a wavelength-matched, narrow beam, infrared light emitting diode, and a signal amplifier. The infrared sensor and signal amplifier are based on the HOBS turbidimeter (Orwin and Smart, 2005); however, the detector/emitter arrangement is inline rather than parallel. Hence, when the turbidity increases, the detector amperage goes down due to occlusion and scattering of the infrared source beam. The turbidimeter sensor is integral with the outlet tube, as shown in Figure 8.

\section{Detector/Emitter LED's}

The detector is an $880 \mathrm{~nm}$ hermetically sealed infrared detector with a mA output. A high precision resistor is used to convert the amperage signal to a D.C. $\mathrm{mV}$ signal, which is sent to an 
amplifier and data recorder. The detector is excited by an in-line $880 \mathrm{~nm}$ infrared emitter with a narrow beam angle of 8 degrees. The narrow beam is used to minimize backscatter. The turbidity is measured as a function of how much light is occluded during the test. The detector and emitter are placed very close together at opposite sides of the outlet tube and effluent from the load cell flows between them during the test. Holes are drilled into opposite sides of the outlet tube to receive the detector and emitter, which are glued into place. The entire arrangement is encapsulated in an NPT threaded, Schedule 40, PVC fitting that attaches to the threaded outlet hole of the load cell. The detector and emitter, outlet pipe, and most of the PVC fitting are encased in clear acrylic to help seal the sensor and prevent damage to the detector/emitter wiring. The PVC fitting is used to electrically isolate the LED and Detector from the aluminum load cell.

\section{Signal Amplifier}

The signal amplifier circuit diagram is presented in Orwin and Smart (2005). However, only the output signal from the first IC amplifier was measured and an external D.C. power source was used in lieu of the D.C. inverter. Only one IC amplifier was used to limit the increase in the $\mathrm{mV}$ signal from the detector to a maximum of 10 volts, which was the limit of the data logger used in the experiments.

The turbidimeter is calibrated with a 4000 NTU Formazin standard. Dilutions of 5, 10, 20, 50, 100 , and $200 \mathrm{ppm}$ were prepared and allowed to flow through the outlet pipe. Readings of voltage and calibration standard concentrations are plotted on a graph, which is used to interpret the results of the tests. For this testing, the calibration standards were also checked against an 
Orbeco-Hellige Digital-Reading Turbidmeter. However, in the case of clean sand, calibration was not necessary as piping is indicated when the sand enters the outlet tube en-masse, effectively occluding the detector immediately upon pipe initiation. Hence, the figures report the direct turbidimeter readings in units of $\mathrm{mV}$, rather than turbidity units. 


\section{Pressurized Water Source, and Pressurized Receiving Vessels}

Any water-compatible tank capable of withstanding internal pressures up to $+30 \mathrm{psi}(207 \mathrm{kPa})$ and a vacuum of $-8.7 \mathrm{psi}(-60 \mathrm{kPa})$ is sufficient for the pressurized water source. The receiving vessel must be small enough and light weight enough to fit on a scale and be capable of containing volume of water of 2 to 3 liters.

\section{Instrumentation and Data Logging Equipment}

The instrumentation consists of two high accuracy pressure transmitters capable of reading a range of pressures of from 0 to $25 \mathrm{psi}(0$ to $172 \mathrm{kPa})$ with output signal ranging from 0.1 to 5.1 VDC. These transducers are used to monitor the inlet and outlet pressures and for evaluation of the internal pore pressures rather than to determine the hydraulic gradient. Pressure transducers for this pressure range (psi) are not sensitive enough to be used to evaluate the hydraulic head (inches). The drop in head across the load cell is measured with a wet/wet differential pressure transmitter, capable of monitoring differential pressures of 0 to 10 inches ( 0 to $254 \mathrm{~mm}$ ) of water $(+/-1 \%$ full scale accuracy) under fluid pressures up to $20 \mathrm{psi}(138 \mathrm{kPa})$. A gram scale with a maximum of $4000 \mathrm{~g}$ and accuracy of 0.01 grams is used to monitor the total amount of effluent being discharged during the test. The flow rate into the load cell is controlled using a glass panel-mount flow meter with valve, with an operating range of 4.95 to $44.60 \mathrm{~mL} / \mathrm{min}(+/-3 \%$ accuracy) for low-flow tests. For tests requiring higher flow rates, a polycarbonate panel mount flow meter with valve (+/-4\% accuracy), with an operating range of $12.6 \mathrm{~mL} / \mathrm{min}(0.2 \mathrm{gph})$ to $157.7 \mathrm{~mL} / \mathrm{min}$ (2.5 gph) was used. These rate of in-flow readings are manually recorded. An analog data logger is used to capture the data from the pressure transmitters, the turbidimeter, 
and the differential pressure gage. The signal from the data logger was processed using a commercial software package. The data from the scale was captured using another software package compatible with the type of scale used in the experiments. Signals to the data logger were sampled every 100 milliseconds, while data from the scale were sampled every second. All data were recorded on a $500 \mathrm{MHz}$ Pentium PC in a format that could be further processed with commercially available spreadsheet software.

\section{SAMPLE AND EQUIPMENT PREPARATION}

\section{Source water}

Deionized water was used in these experiments. Deionized water was selected to provide the most conservative estimate of piping potential. Although none of the soil samples tested were dispersive, deionized water would yield the most conservative estimate of pipe initiation if dispersive soils were encountered. The deionized water was pretreated by applying a vacuum of $-8.7 \mathrm{psi}(-60 \mathrm{kPa})$ for 24 hours before the test. A micro-pore filter was used to filter any contaminants from the Source Vessel before it passed through the final granular deairing filter and entered the soil sample.

\section{General Soil Characterization}

The samples were characterized using standard ASTM methods. Characterization conformed to the Unified Soil Classification System. If necessary, the soils should also be tested for dispersivity. The Double Hydrometer and Pinhole Test can be used to evaluate dispersivity. The soil used in these initial tests is non-dispersive. 


\section{Sample Preparation}

The samples were screened through a No. 4 sieve to remove over-sized particles prior to performing the piping tests. Although not done here, in widely or gap graded materials containing gravels, it is necessary to keep the coarser materials in the sample in order to test susceptibility to suffusion. However, in samples with internally stable gradations, such as in our test soil, the minus No. 4 fraction was used.

\section{Loading the Soil into Load Cell}

Soil is loaded into the load cell by inverting the cell and removing the bottom. Prior to loading the soil, the thin steel plate must be temporarily inserted into the grooves on the inside of the load cell. The screen is placed against the steel plate and pea gravel is worked into the inlet side of the load cell into a compact arrangement. The steel plate will hold the gravel and screen inplace. The soil was then be placed into the load cell, and after it is placed at its desired density, the steel plate is removed, the gravel drain topped off with more gravel if needed, the bottom (with rubber gasket) reattached to the load cell, and the load cell carefully inverted and placed on a stand in its test position. The sample is loaded from the bottom of the cell because it is easier than loading from the top of the cell, which has an air bladder attached to it. Finally, the inlet and outlet valve trees are then connected, the differential pressure gage monitoring lines connected, and the turbidimeter and pressure transducers plugged in and the data logger and PC turned on. 
Samples can be compacted to simulate field conditions while loading the cell. However, in the case of these initial tests, the sample was placed in its loosest state using the funnel method described in ASTM D4254. When testing samples for a specific work site, they should be compacted in the load cell in a similar moisture/density condition as the in-situ soil.

\section{Evacuating Air and Saturating Soil}

After the load cell was filled with soil and inverted to its test position and all other equipment attached to the load cell, the vacuum line was attached (using a quick-release fitting) from the Inlet-Outlet Pressure Control Panel to the inlet valve tree. The inlet-outlet pressure control panel valves are configured for vacuum generation. An $8.7 \mathrm{psi}(60 \mathrm{kPa})$ vacuum was applied to the load cell for 10 minutes to help remove air from the soil sample. After the 10 minutes, the lower valve on the inlet valve tree was closed and the vacuum line removed.

The pressurized receiving vessel is allowed to remain open to atmospheric pressure and the outlet valve tree valves opened slightly to allow water to gradually fill the vacuum and saturate the soil sample in the load cell. The rate of filling should not exceed the flow rate at which piping is triggered. A rate of 0.1 gallons per hour was sufficient for the samples tested here.

A pressure of $10 \mathrm{psi}(69 \mathrm{kPa})$ was applied to the pressurized water source vessel. The receiving vessel is then attached to the outlet valve tree via a quick release fitting, and a $5 \mathrm{psi}(34 \mathrm{kPa})$ pressure is then applied to the pressurized receiving vessel. The valves on the outlet valve tree are opened slightly to allow water to fill the remaining part of the load cell and the inlet valve tree with deaired water. Once the load cell and inlet valve tree are completely filled with deaired 
water, close the valve closest to the load cell in the outlet valve tree and flush any air out of the two monitor lines for the differential pressure gage.

At this point, the soil sample should be completely saturated with deaired water and the inlet and outlet valve trees and differential monitoring lines filled with deaired water and free of any air bubbles. The only valve in the closed position is the valve closest to the load cell in the outlet valve tree. The load cell is open to atmospheric pressure through the quick connect fitting at the end of the inlet valve tree.

\section{Applying Confining Pressures}

The sample is now ready to be loaded by application of confining stress through the air bladder pistons. During this operation, some water will be discharged out the inlet valve tree. If the volume change of the soil is needed, this discharge should be collected and measured. The confining pressures are applied by connecting the air lines to the load cell and conveying compressed air from the inlet-outlet pressure control panel to the manifold in the air bladder pressure control panel. The actual air pressures within the air bladders are not the same pressure that is applied to the soil. Since the air bladders deform and curve when filled with the air, the contact area between the bladder and the steel plate is slightly less than the total area of the plate. Hence, the actual force applied to the steel plate should be computed. The required air pressure was determined by previous calibration of the area of contact of the air bladders versus pressure within the air bladders. The area of contact was used to compute the force being applied to the steel plate in the air bladder piston. The area of contact was approximately $85 \%$ of the total bladder area under the pressures used in these tests. This force is then distributed by the steel 
plate over the internal cross sectional area of the load cell. The pressures applied to the soil was computed as the applied force divided by the cross sectional area of the steel plates in the air bladder pistons. The required air pressure was applied to each of the air bladders through gradual, incremental adjustments so as not to quickly disturb the sample. It is important that the outlet valve tree valve remained closed throughout this operation.

\section{Equalizing Pressures, Opening Outlet Valve}

Once the soil is under the appropriate confining stresses, air is bled from the inlet flow tube that conveys water from the inlet flow-control panel and the male quick release connection at the end of the inlet flow tube connected to the quick release connection at the end of the inlet valve tree. With the outlet valve tree valve still in the closed position, the flow regulator is opened on the flow control panel to allow water to flow into the load cell. The pore pressures within the load cell are monitored until the pore pressure in the load cell increases and levels off to the value desired for the test. The load cell now contains saturated soil with set confining stresses and pore pressure.

Before the valve on the outlet valve tree can be opened, the pressure in the pressurized receiving vessel must be carefully increased until the differential pressure gage indicates a near-zero differential pressure across the load cell. Once the differential pressure is near zero, the valve may be opened on the outlet valve tree to begin the test. 


\section{TEST PROCEDURE}

\section{Adjust Flow Through Load Cell}

After initiating the data logging equipment, the flow regulator is adjusted upwards in increments of $5(\mathrm{ml} / \mathrm{min}) / \mathrm{min}$, gradually increasing the rate of flow through the soil. After a number of tests, it was found that there was no advantage to allowing the flow to remain steady for long periods of time between incremental increases to the rate of flow. One of the initial tests was to further assess the impact of the rate of change of the flow rate. We found that allowing the flow to stabilize for 45 seconds was sufficient. During the next 15 second period, the flow rate was increased another $5 \mathrm{ml} / \mathrm{min}$. The total rate of increase was then $5(\mathrm{ml} / \mathrm{min}) / \mathrm{min}$. This confirms the work of Tomlinson and Vaid (2000), who also found no benefit in allowing flow to remain steady for a long period between increases. However, we also found that sudden large increases in flow rate can affect the critical velocity at which piping initiates (as did Tomlinson and Vaid, 2000). This effect was observed during sudden opening or closing of valves, which may induce a water-hammer effect within the apparatus that can trigger premature movement of soil. To avoid a water hammer, the adjustments to flow rate must be made slowly and incrementally. These slow increases in flow rate, with a 45 second rest resulted in stable differential head conditions up to the time piping initiated.

\section{Data Recording Requirements}

The data logging equipment and software record the inlet and outlet pressures, the voltage across the turbidimeter (which can be correlated to NTU's based on the calibration graph), and the 
differential pressure gage. Only three items need be manually recorded during the test. These are 1) time, 2) in-flow rate, 3) comments. While running the test it is best to have a real-time graphical presentation of the turbidimeter readings so the onset of piping can be noted. This will help to determine when to end the test.

\section{Data Interpretation}

The instrument data is consolidated and plotted on an X-Y plot for each test. The data plots allow correlation of the various parameters to better evaluate the overall quality of the test and to determine the conditions at the onset of piping. Figure 9 is an example of the test output from repeatability Test Number 3 . Once piping initiates, the differential head across the instrument began to increase rapidly as more and more soil enters the outlet tube. The outlet pressure also began to increase at a slightly different rate after pipe initiation and the turbidimeter showed a sudden drop in voltage as the sand occludes the detector. Evaluation of these three parameters allowed the determination of the exact conditions at the onset of piping. Pipe initiation was then evaluated from the measured discharge rate at which piping commenced (Richards and Reddy, 2008).

\section{Other Considerations}

From set-up to clean-up, a test requires about three to four hours to complete. Care must be taken while inverting the load cell to prevent soil from prematurely entering the Outlet Tube. It is important to keep the valve next to the turbidimeter in the closed position once the sample has been saturated, until the pressures inside the cell are equalized to the pressure in the outlet tube. Any time a valve is opened, it should be opened carefully and slowly to avoid creating a water 
hammer. The turbidimeter will periodically need to be cleaned and generally must be treated with care, as it is the most fragile instrument and due to the instrument set-up requires frequent handling. Overall, the true triaxial piping test is an easy test to run and provides easily interpreted results.

\section{INITIAL TEST RESULTS}

Three sets of tests were run on a uniform fine SP sand. The purpose of these initial tests was to 1) to assess the repeatability of test results, 2) to evaluate how the rate of change of in-flow rate impacts the critical discharge rate at which piping is initiated, and 3) to evaluate how the angle of seepage affects the critical velocity for piping initiation. Tables 1-3 provide a summary of the tests that were run and the test results. All the tests were run with uniform, fine-grained quartz sand, classified as SP in the Unified Soil Classification System. The sand was manufactured by U.S. Silica and is their F-series sand commonly used in laboratories. The gradation is 99.9 percent passing the No. 20 sieve with only 3.0 percent passing the No. 40 sieve, and only 0.06 percent passing the No. 60 sieve. It contains less than 0.005 percent fines (passing the No. 200 sieve), and has a Coefficient of Uniformity of 1.1. The sand was placed dry, in its loosest state and was tested under similar pore pressure conditions. This material was chosen for the initial tests because it was possible to place the soil at a uniform density during each test, without segregation, and the test results would be free of interference from variations in soil texture, moisture, or density.

\section{Repeatability Tests}


As can be seen in Table 1, the critical velocity for pipe initiation in the repeatability tests fell within a range of $1.1 \mathrm{~cm} / \mathrm{sec}$ to $0.81 \mathrm{~cm} / \mathrm{sec}$, with a mean of $0.98 \mathrm{~cm} / \mathrm{sec}$ and an average of 0.97 $\mathrm{cm} / \mathrm{sec}$ and standard deviation of $0.10 \mathrm{~cm} / \mathrm{sec}$ (approximately $10 \%$ of the average value). The repeatability tests were conducted using similar void ratios, confining stresses, and pore pressures. The rate of change to inflow during the tests was a steady $5(\mathrm{ml} / \mathrm{min}) / \mathrm{min}$ as was described above. One important finding is that the critical hydraulic gradient (as computed from the critical differential heads) was not the best predictor of piping potential and that the critic velocity yielded more consistent results. Both the computed hydraulic conductivity and the hydraulic gradient were found to vary in the repeat tests, which may be indicative of somewhat variable amount of swelling of the soil from test to test. It has previously been observed that soil tends to swell as it approaches its critical piping condition, at which point its void ratio appears to be a constant (Terzaghi, 1943). When soil swells to its critical piping state, its hydraulic conductivity increases. The critical flow (Q) when piping is initiated is the product of the hydraulic conductivity (k), the cross sectional area of seepage (A), and the hydraulic gradient (i) according to Darcy's law. The critical gradient and critical hydraulic conductivity were observed to change irregularly in these tests while the cross sectional area of seepage was constant. The product of critical gradient and critical hydraulic conductivity was fairly constant from test to test; hence, the critical flow and critical velocity varied little (Richards and Reddy, 2008). We conclude that the critical velocity is the fundamental property responsible for piping in noncohesive materials and as such, is a better measure to use when evaluating piping problems. The 0.10 standard deviation within the data set can be partially explained by the cumulative accuracy of the various gages and regulators used in TTPTA, some which have an accuracy of $3 \%$ to $4 \%$. Some of the error may also be due to the placement method yielding slightly 
different void ratios and minute variations in seepage paths within the sample from test to test. Pore pressures may also have influenced the results but more testing would be required to evaluate this effect, as the data obtained during these tests do not show a systematic variation within the small ranges of pore pressure tested. For example, test number 5 had the lowest pore pressure but did not yield the highest critical velocity as might be expected.

A standard deviation of $10 \%$ is not unheard of in geotechnical testing; however, the test results from these initial tests are much better if the one outlier (test no 4) is thrown out. If this test is removed, the standard deviation drops to 0.057 (approximately 5.6\%, which is in-line with the cumulative accuracy of the instrumentation). It should be possible, with a minimum number of repeat tests, to determine the value of the critical piping velocity for a cohesionless soil with confidence using the TTPTA.

\section{Rate of Change Tests}

As was previously discussed, during development of the test we were concerned that the rate of change to the inflow might influence the test results. We noted that when the inflow rate is suddenly increased, as when a valve was suddenly opened, piping could be triggered at lower computed flow velocities. However this effect may be due to water hammer causing a hydraulic pressure transient. In nature, we would not expect this type of a transient force to occur. There are cases of dam failures by piping when a reservoir is raised rapidly, which may induce a fast but more gradual increase in seepage flow rates than that caused by suddenly opening a valve. Several trials were run to determine the potential magnitude of any effect of rapidly increasing flow rates. Table 2 shows the tests that were run to assess this impact (note that we have 
excluded the outlier Test Number 4 that was discussed in the previous section). Figure 10 summarizes the results for the rate of change tests graphically. There is an apparent non-linear relationship with an apex around $6(\mathrm{ml} / \mathrm{min}) / \mathrm{min}$, although the data points for rates of change $(\varsigma)$ equal to and less than $5(\mathrm{ml} / \mathrm{min}) / \mathrm{min}$ fall within the $\pm 10 \%$ error envelope of anticipated variation found in our repeatability tests. The data for the $11(\mathrm{ml} / \mathrm{min}) / \mathrm{min}$ tests indicate there may be an effect that reduces the critical velocity to induce piping for more rapid changes to the inflow rates. Overall, we found a rate of increase of in-flow of $5.0(\mathrm{ml} / \mathrm{min}) / \mathrm{min}$ adequate. Testing at this rate may yield a slightly higher critical velocity than tests conducted at faster or slower rates. However, it is a more realistic rate of increase than the $11(\mathrm{ml} / \mathrm{min}) / \mathrm{min}$ rate. It is also a more efficient rate to conduct the tests than the much slower rate of $1.25(\mathrm{ml} / \mathrm{min}) / \mathrm{min}$ yet yields approximately the same result.

\section{Seepage Angle Tests}

Seepage angle tests were designed to determine if the seepage angle has any effect on the critical velocity at pipe initiation. Current piping evaluation methods consider how the hydraulic gradient at the toe of a dam compares to a critical hydraulic gradient computed from the effective unit weight of soil. Skempton \& Brogan (1994) proposed that there is a reduction factor, depending on the amount of stresses carried by an unstable fraction of soil, that reduces the critical hydraulic gradient necessary to commence piping;

$$
i_{c}=\alpha \gamma^{\prime} / \gamma_{w}
$$

Where: $i_{c}=$ critical hydraulic gradient

$$
\begin{aligned}
& \alpha=\text { reduction factor } \\
& \gamma^{\prime}=\text { effective unit weight of soil }
\end{aligned}
$$




$$
\gamma_{w}=\text { unit weight of water }
$$

This equation is based on the earlier work of Terzaghi (1943) that was based on uplift at the bottom of a cofferdam. The equation does not consider the seepage direction, perhaps because the seepage direction in Terzaghi's problem is directly upward, acting against gravity. What is effect when the seepage direction has a component that acts with gravity to destabilize the soil. One would expect that if the seepage path is downhill, the component of gravity parallel to the seepage path is acting to help destabilize the soil grains. In contrast, if the seepage path is uphill, the component of gravity parallel to the seepage path is acting to stabilize the soil grain. Intuitively, gravity should have a significant effect on the critical velocity to induce piping. If this is true, then the orientation of piping tests is very critical and should mirror the conditions in the field. Tests conducted with seepage acting vertically downward should not be comparable to test acting vertically upward, and neither sets of test are comparable to tests conducted with seepage acting horizontally because the effects of gravity are different in all these cases.

Table 3 shows the tests that were run to evaluate how the orientation of the test may impact the critical velocity at pipe initiation. The tests were run at similar confining stresses and pore pressures. Only two angles $(\beta)$ were tested; $-10^{\circ}$ from horizontal and +10 degrees from horizontal. Each test was run twice to confirm the previous result. The TTPTA was tilted for each test but was otherwise conducted in the same way as described previously. Figure 11 provides the graphical results for the seepage angle test. There is a trend of increasing critical velocity with increasing the seepage angle above horizontal. In fact, the critical velocity required to induce piping in one test $(1.33 \mathrm{~cm} / \mathrm{sec})$ was significantly greater than the $0.97 \mathrm{~cm} / \mathrm{sec}$ average 
value we obtained in the horizontal, repeatability tests. Conversely, in the two tests that were run with the seepage angle $10^{\circ}$ below the horizontal, the critical velocity was as low as $0.65 \mathrm{~cm} / \mathrm{sec}$. These initial test apparently confirm that gravity, and the seepage direction have a significant influence on the critical velocity required to induce piping.

\section{CONCLUSIONS}

The TTPTA is a relatively low cost apparatus for evaluating a wide variety of soils prone to backwards erosion. It can be used to evaluate non-cohesive as well as pervious cohesive materials subjected to a variety of loading conditions, and is therefore capable of simulating conditions within a zoned embankment. Confining stresses along three mutually perpendicular axes can be varied in the test, as can the internal pore pressure and seepage flow rate. This test has some advantages over the pinhole test and the hole erosion and slot erosion tests in that it is capable of handling a wider variety materials, including cohesionless soil. The apparatus can be oriented to test a range of seepage orientations, ranging from vertical to horizontal flow.

Repeatability tests conducted under horizontal flow conditions found that the data results have a standard deviation of about $10 \%$ of the average test value. However, if the outlier sample is removed from the data set, the standard deviation is reduced to about 5.6\%. Overall, the method demonstrates a reasonable reproducibility and appears to be a good method to determine the critical velocity required to induce backwards erosion piping. A set of tests were conducted to evaluate the rate of increase using the TTPTA. The results indicate that rates less than about 6 $(\mathrm{ml} / \mathrm{min}) / \mathrm{min}$ fall within the expected range of expected values. A rate of increase of 11 $(\mathrm{ml} / \mathrm{min}) / \mathrm{min}$ resulted in a slightly lower value for the critical velocity at pipe initiation, but may be too fast a rate to simulate real conditions at a dam. Additional tests are being done to further 
define other critical parameters that influence pipe initiation using the TTPTA. 


\section{REFERENCES}

Adel, H., Baker, K.J., and Breteler, M.K., 1988, “Internal Stability of Minestone”, Proc. Int. Symp. Modelling Soil-Water-Structure Interaction, Balkema, Rotterdam, pp 225-231.

Aitchison. G.D., Ingles, O.G., and Wood, C.C., 1963, "Post-Construction Deflocculation as a Contributory Factor in the Failure of Earth Dams", Proc. of the Fourth ANZ Conf. on Soil Mech. and Found. Engrg., Institution of Engineers, Australia, pp 275-279.

Bertram, G.E., 1940, “An Experimental Investigation of Protective Filters”, Soil Mechanics Series No. 7, Graduate School of Engineering, Harvard University, Cambridge, Mass., pp. 7-8.

Bligh, W.G., 1910, "Dams, Barrages and Weirs on Porous Foundations", Engineering News, ASCE, p. 708.

Briaud, J.L., Ting, F.C.K., Chen, H.C., Cao, Y., Han, S.W., and Kwak, K.W., 2001. “Erosion Function Apparatus for Scour Rate Predictions", J. of Geot. And Geoenv. Eng., ASCE, Vol. 127(2), pp. 105-113.

Decker, R.S., and Dunnigan, L.P., 1977, “Development and Use of the Soil Conservation Service Dispersion Test", Dispersive Clays, Related Piping, and Erosion in Geotechnical Projects, ASTM STP 623, pp. 94-109.

Kakuturu, S.P., 2003, "Modeling and Experimental Investigations of Self-healing or Progressive Erosion of Earth Dams", Ph.D. Dissertation, Kansas State University, Manhattan, KS, pp. $75-166$.

Moore, W.L., and Masch, F.D., 1962, "Experiments On the Scour Resistance of Cohesive Sediments", J. Geophys. Res., Vol 67(4), pp. 1437-1449. 
Orwin, J.F., and Smart, C.C., 2005, “An Inexpensive Turbidimeter for Monitoring Suspended Sediment", Geomorphology, Vol. 68, pp. 3-15.

Richards, K.S., 2008, "Piping Potential of Unfiltered Soils in Existing Levees and Dams”, Ph.D. Thesis, University of Illinois at Chicago, Illinois.

Richards, K.S., and Reddy, K.R., 2007, "Critical Appraisal of Piping Phenomena in Earth Dams”, Bull. Eng. Geol. Environ., Vol.66, pp.381-402.

Richards, K.S., and Reddy, K.R., 2008, “Experimental Investigation of Piping Potential in Earthen Structures”, GeoCongress 2008, New Orleans, ASCE GeoInstitute Conference Proceedings.

Sherard, J.L., Dunnigan, L.P., Decker, R.S., and Steele, E.F., 1976, "Pinhole Test for Identifying Dispersive Soils", Jour. of the Geot. Engrg. Div., ASCE, pp. 69-85.

Skempton, A.W., and Brogan, J.M., 1994, "Experiments on Piping in Sandy Gravels", Geotechnique, Vol. 44(3), pp. 449-460.

Terzaghi, K. (1922) "Der Grundbruch an Stauwerken und seine Verhutung (The failure of dams by piping and its prevention)", Die Wasserkraft, Vol. 17, 1922, pp. 445-449. Reprinted in "From theory to practice in soil mechanics", John Wiley and Sons, New York, 1960.

Terzaghi, K. (1943) “Theoretical Soil Mechanics”, John Wiley and Sons, Inc., New York, pp. 1510.

Tomlinson, S.S., and Vaid, Y.P., 2000, "Seepage Forces and Confining Pressure Effects on Piping Erosion", Can. Geotech. J., Vol. 37, pp. 1-13.

Valdes, J.R., and Liang, S.H., 2006, "Stress-controlled filtration with compressible particles", J. Geotech. Engrg., July, pp. 861-868. 
Wan, C.F., and Fell, R., 2002, "Investigation of Internal Erosion and Piping of Soils in Embankment Dams by the Slot Erosion Test and the Hole Erosion Test", UNICIV Rept. R-412, Univ. of New South Wales, Sydney, Australia.

Wan, C.F., and Fell, R., 2004, “Investigation of Rate of Erosion of Soils in Embankment Dams”, Jour. of Geotech. and Geoenvir. Engrg., ASCE, pp. 373-380. 
Table 1. Initial Tests - Repeatability Tests (outlet tube diameter $0.52 \mathbf{c m}^{2}$ )

\begin{tabular}{|c|c|c|c|c|c|c|c|c|c|}
\hline \multirow{2}{*}{$\begin{array}{l}\text { Test } \\
\text { No. }\end{array}$} & \multicolumn{5}{|c|}{ Test Conditions } & \multicolumn{4}{|c|}{ Test Results at Pipe Initiation } \\
\hline & $\begin{array}{c}\sigma_{1} \\
(\mathrm{kPa})\end{array}$ & $\begin{array}{c}\sigma_{2} \\
(\mathrm{kPa})\end{array}$ & $\begin{array}{c}\boldsymbol{\sigma}_{3} \\
(\mathrm{kPa})\end{array}$ & $\underset{(\mathrm{kPa})}{\mathbf{u}}$ & $\begin{array}{l}\mathrm{s} \\
\mathrm{ml} / \\
\min / \\
\min \end{array}$ & $\begin{array}{l}\text { Critical } \\
\text { Velocity } \\
(\mathrm{cm} / \mathrm{sec})\end{array}$ & $\begin{array}{c}\text { Critical } \\
\text { Flow } \\
\text { (cm3/sec) }\end{array}$ & $\begin{array}{c}\text { Critical } \\
\text { Differential } \\
\text { Head } \\
(\mathbf{c m})\end{array}$ & $\begin{array}{c}\text { Critical } \\
\text { Gradient }\end{array}$ \\
\hline 1 & 79.2 & 60.5 & 42.0 & 29.1 & 5 & 1.1 & 0.55 & 2.4 & 0.18 \\
\hline 2 & 79.2 & 60.5 & 42.0 & 28.1 & 5 & 0.98 & 0.51 & 1.8 & 0.13 \\
\hline 3 & 79.2 & 60.5 & 42.0 & 28.0 & 5 & 0.98 & 0.51 & 2.5 & 0.19 \\
\hline 4 & 79.2 & 60.5 & 42.0 & 26.9 & 5 & 0.81 & 0.42 & 2.9 & 0.22 \\
\hline 5 & 79.2 & 60.5 & 42.0 & 24.7 & 5 & 1.0 & 0.54 & 3.3 & 0.24 \\
\hline
\end{tabular}

Table 2. Initial Tests - Inflow Rate Tests (No. 4 test is not included in this data set)

\begin{tabular}{|c|c|c|c|c|c|c|}
\hline \multirow{2}{*}{ Nest } & \multicolumn{5}{|c|}{ Test Conditions } & $\begin{array}{c}\text { Test Results at } \\
\text { Pipe Initiation }\end{array}$ \\
\cline { 2 - 7 } & $\begin{array}{c}\boldsymbol{\sigma}_{1} \\
(\mathbf{k P a})\end{array}$ & $\begin{array}{c}\boldsymbol{\sigma}_{\mathbf{2}} \\
(\mathbf{k P a})\end{array}$ & $\begin{array}{c}\boldsymbol{\sigma}_{3} \\
(\mathbf{k P a})\end{array}$ & $\begin{array}{c}\mathbf{u} \\
(\mathbf{k P a})\end{array}$ & $\begin{array}{c}\mathbf{S} \\
\mathbf{m l} / \\
\mathbf{m i n} / \\
\mathbf{m i n}\end{array}$ & $\begin{array}{c}\text { Critical Velocity } \\
(\mathbf{c m} / \mathbf{s e c})\end{array}$ \\
\hline 1 & 79.2 & 60.5 & 42.0 & 29.1 & 5 & 1.1 \\
\hline 2 & 79.2 & 60.5 & 42.0 & 28.1 & 5 & 0.98 \\
\hline 3 & 79.2 & 60.5 & 42.0 & 28.0 & 5 & 0.98 \\
\hline 5 & 79.2 & 60.5 & 42.0 & 24.7 & 5 & 1.0 \\
\hline 6 & 79.2 & 60.5 & 42.0 & 25.6 & 11 & 0.83 \\
\hline 7 & 79.2 & 60.5 & 42.0 & 25.1 & 1.25 & 0.87 \\
\hline 8 & 79.2 & 60.5 & 42.0 & 24.8 & 2.5 & 0.96 \\
\hline 9 & 79.2 & 60.5 & 42.0 & 28.0 & 5 & 0.98 \\
\hline
\end{tabular}


Table 3. Initial Tests - Seepage Angle Tests $(\beta=$ degrees from horizontal)

\begin{tabular}{|c|c|c|c|c|c|c|}
\hline Test & \multicolumn{5}{|c|}{ Test Conditions } & $\begin{array}{c}\text { Test Results at } \\
\text { Pipe Initiation }\end{array}$ \\
\cline { 2 - 7 } No. & $\begin{array}{c}\boldsymbol{\sigma}_{\mathbf{1}} \\
(\mathbf{k P a})\end{array}$ & $\begin{array}{c}\boldsymbol{\sigma}_{\mathbf{2}} \\
(\mathrm{kPa})\end{array}$ & $\begin{array}{c}\boldsymbol{\sigma}_{\mathbf{3}} \\
(\mathrm{kPa})\end{array}$ & $\begin{array}{c}\mathbf{u} \\
(\mathbf{k P a})\end{array}$ & $\begin{array}{c}\boldsymbol{\beta} \\
\mathbf{a n g l e}\end{array}$ & $\begin{array}{c}\text { Critical Velocity } \\
(\mathbf{c m} / \mathbf{s e c})\end{array}$ \\
\hline 10 & 80.8 & 42.0 & 42.0 & 26.8 & 10 & 1.05 \\
\hline 11 & 80.8 & 42.0 & 42.0 & 24.4 & -10 & 0.65 \\
\hline 12 & 80.7 & 42.0 & 42.0 & 24.9 & 10 & 1.33 \\
\hline 13 & 80.7 & 42.0 & 42.0 & 24.9 & -10 & 0.87 \\
\hline
\end{tabular}




\section{Figure Captions}

Figure 1. Photograph of true triaxial load cell at the heart of the TTPTA with the load cell loaded and in its test position.

Figure 2. The TTPTA system layout consists of several components, which are outlined schematically in Figures 3-8.

Figure 3. Inlet-Outlet Pressure Control Panel diagram.

Figure 4a. Photograph of the Inlet-Outlet Pressure Control Panel and Vacuum Generator

Figure 4b. Photograph of the Inlet-flow Control Panel

Figure 4c. Photograph of the Air Bladder Control Panel

Figure 5. Schematic of the Inlet-flow Control Panel

Figure 6. Schematic of the Air Bladder Piston.

Figure 7. Schematic of the Inlet/Outlet Valve Trees.

Figure 8. General schematic of the Flow-Through Turbidimeter sensor with in-line LED emitter and detector.

Figure 9. Example of graphed TTPTA output for a clean, uniform sand sample. Note how the turbidimeter is suddenly occluded when sand begins piping into the outlet tube. This is indicative of pipe initiation.

Figure 10. Inflow rate of change TTPTA results show a non-linear response, with an apex around $6(\mathrm{ml} / \mathrm{min}) / \mathrm{min}$.

Figure 11. Seepage angle test results show a reduction in the critical velocity required to initiate piping when seepage is in a downward direction ( $-\beta$ angles are downward from horizontal). In this orientation, gravity is assisting with the piping process. 


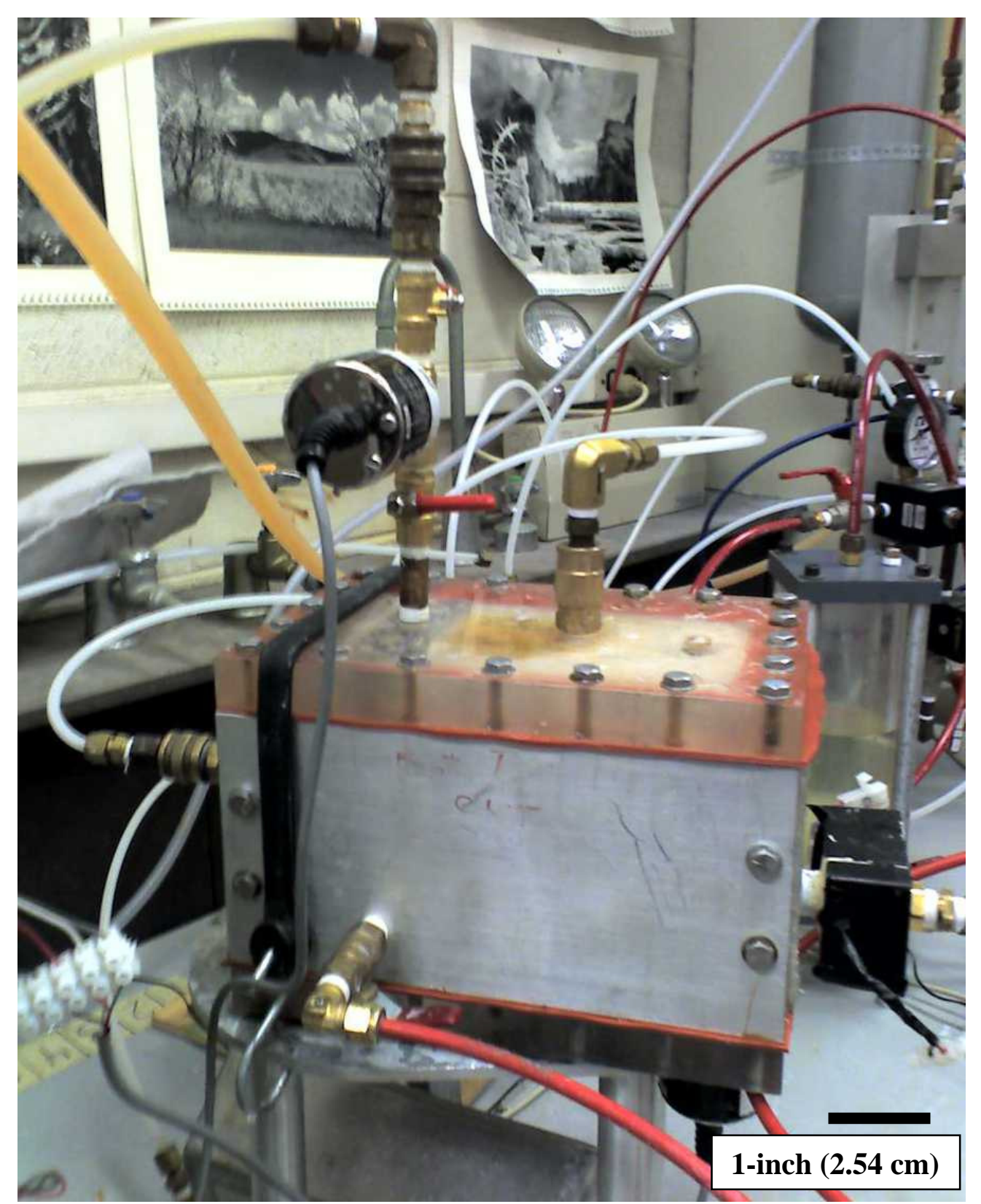


Water Flow

Control Panel
Pressurized Water

Source Vessel
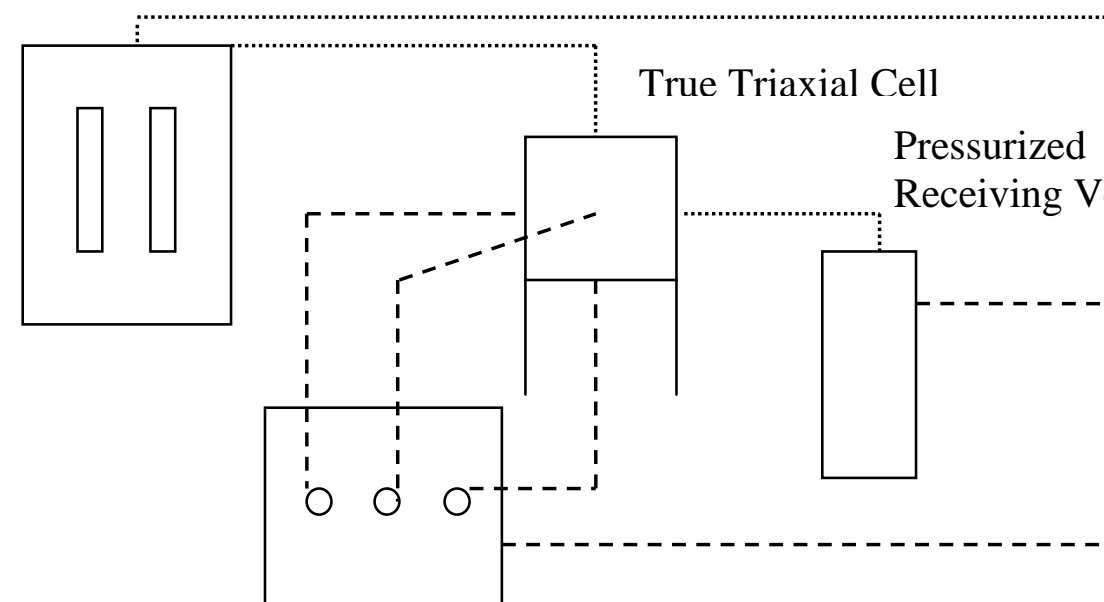

Air Bladder Pressure Control Panel

To Air Compressor

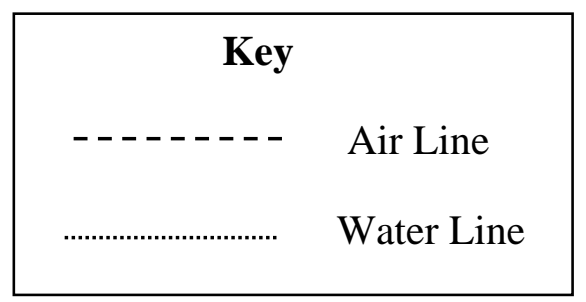




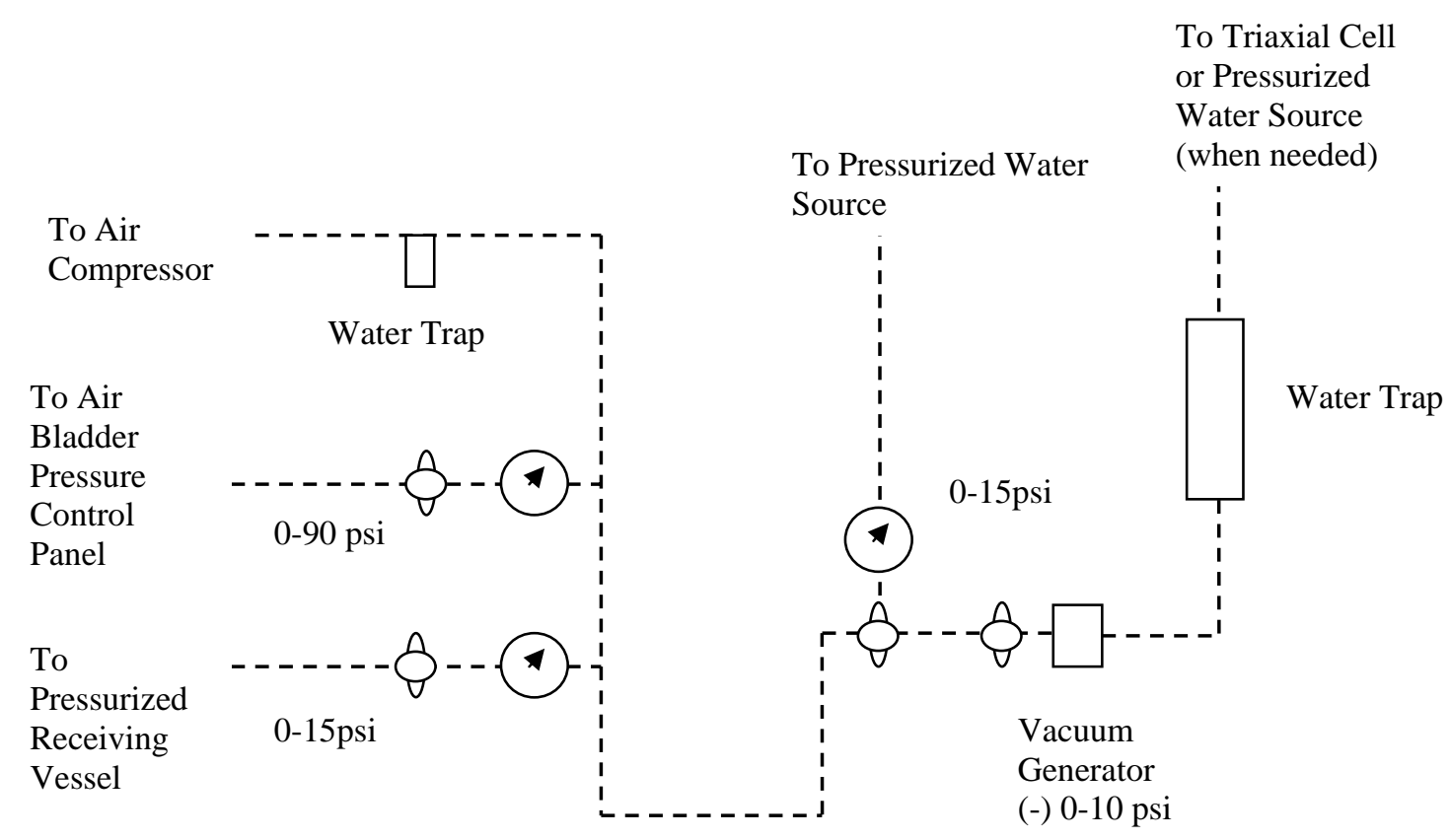




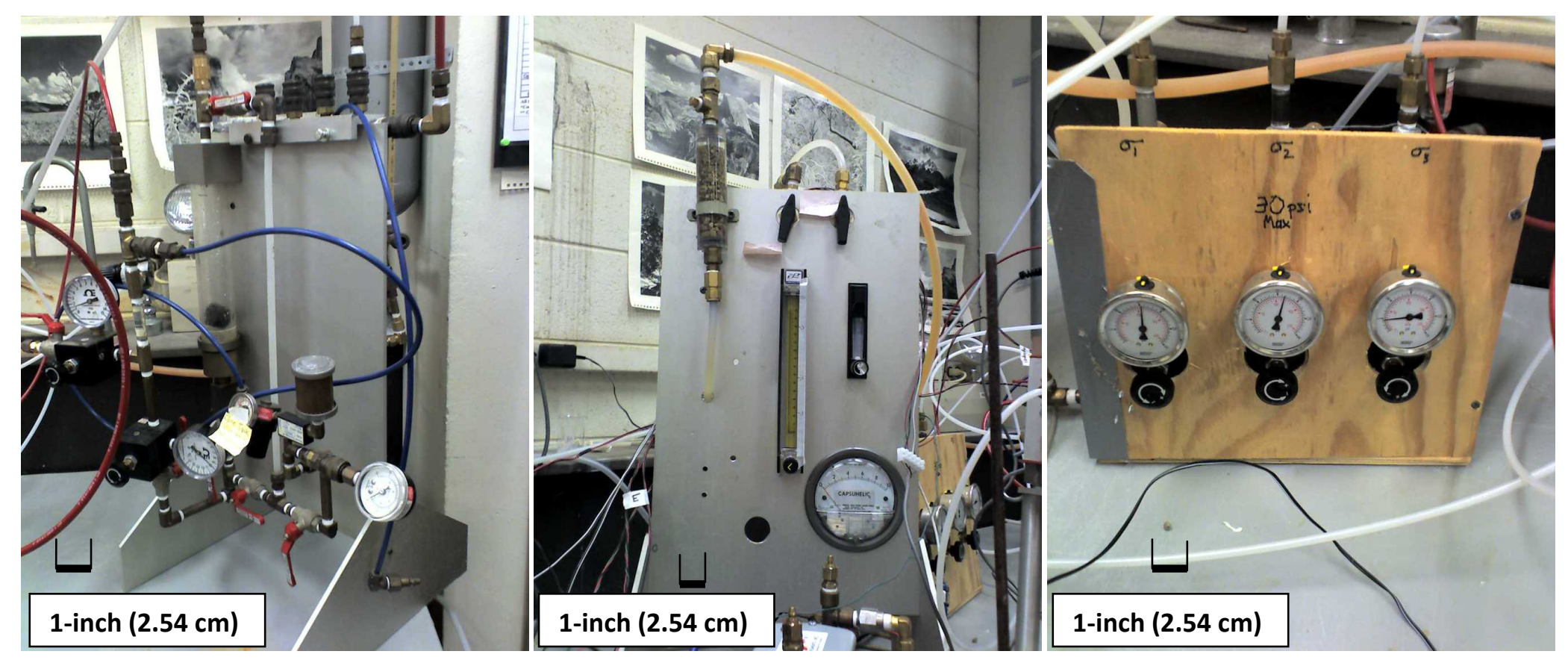

Fig. 4a - Inlet-Outlet Pressure Control Panel

Fig. 4b - Inlet Flow-Control Panel

Fig. 4c - Air Bladder Control Panel 


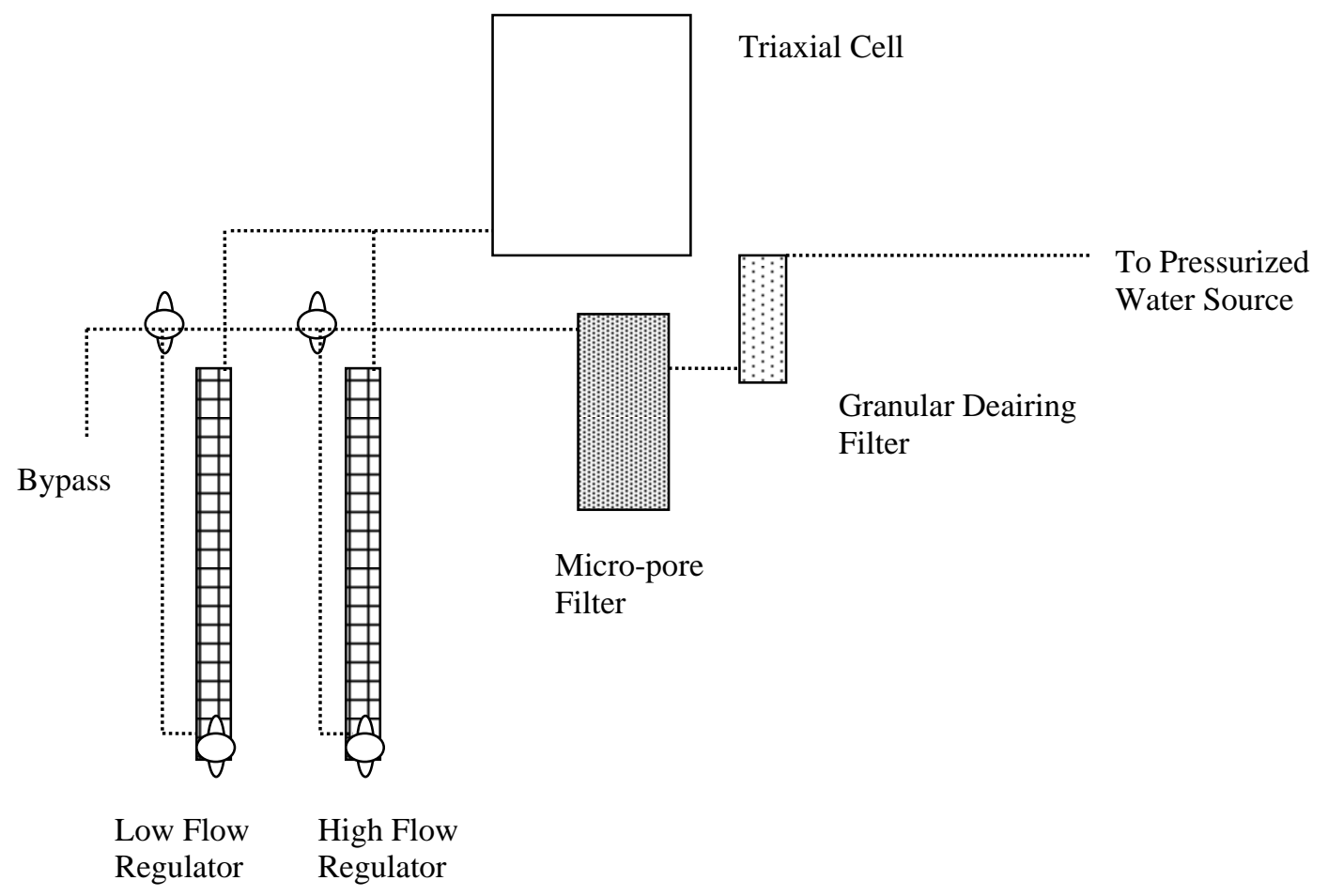




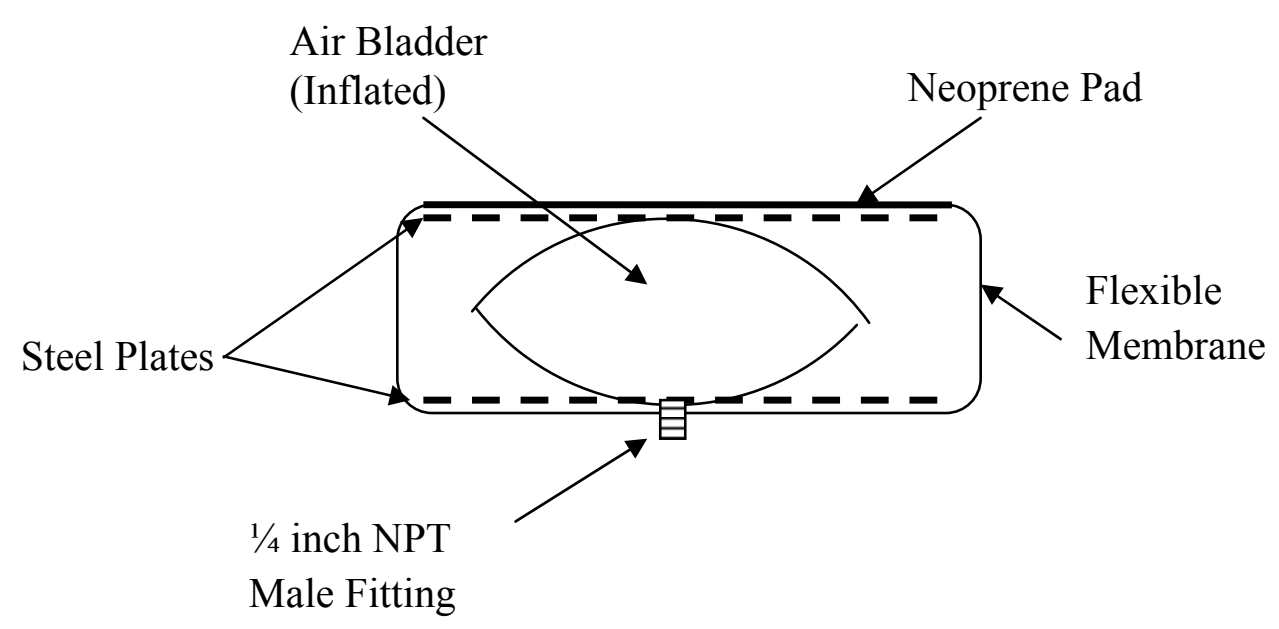




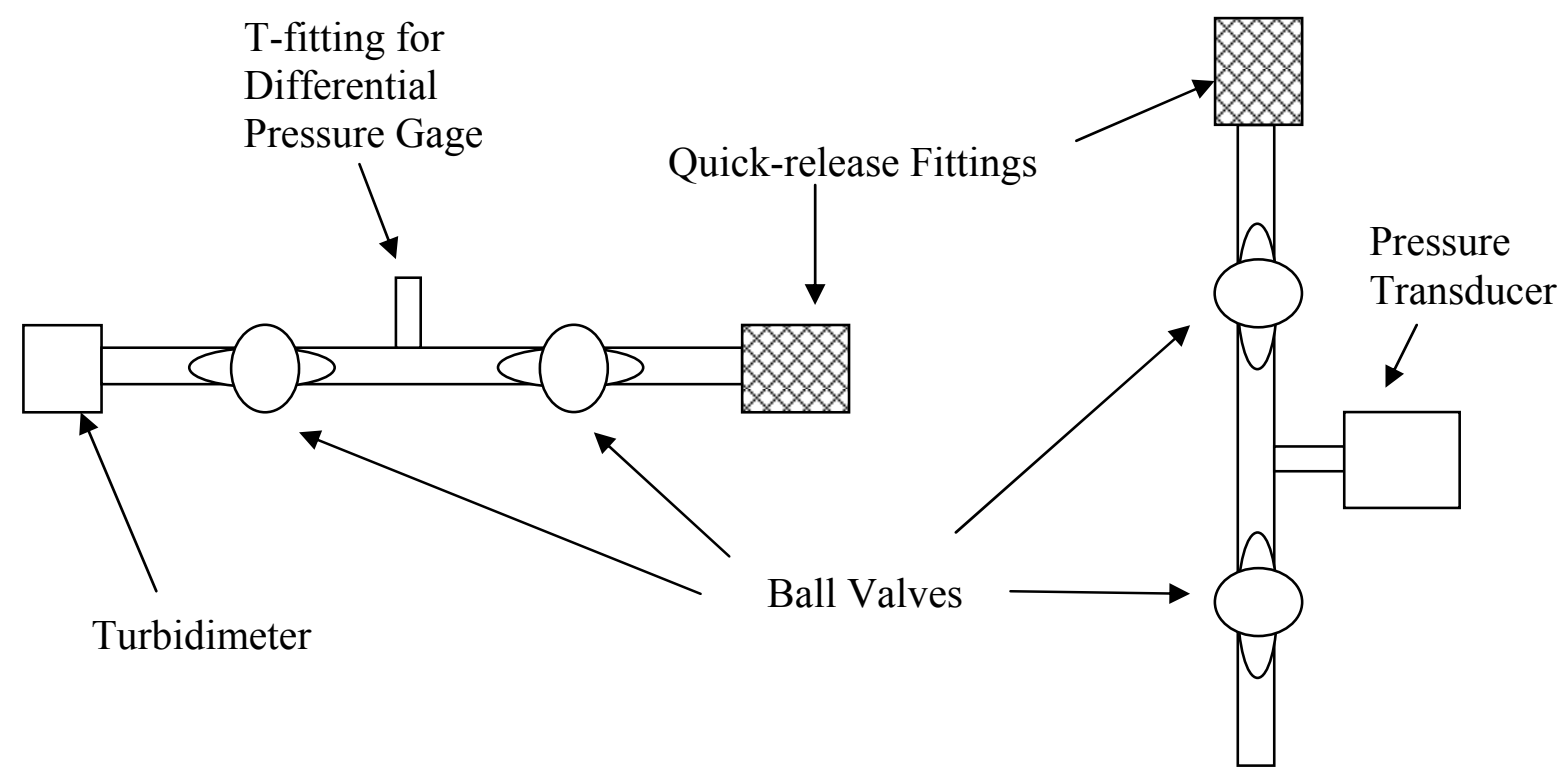

$\underline{\text { Outlet Valve Tree }}$

$\underline{\text { Inlet Valve Tree }}$ 


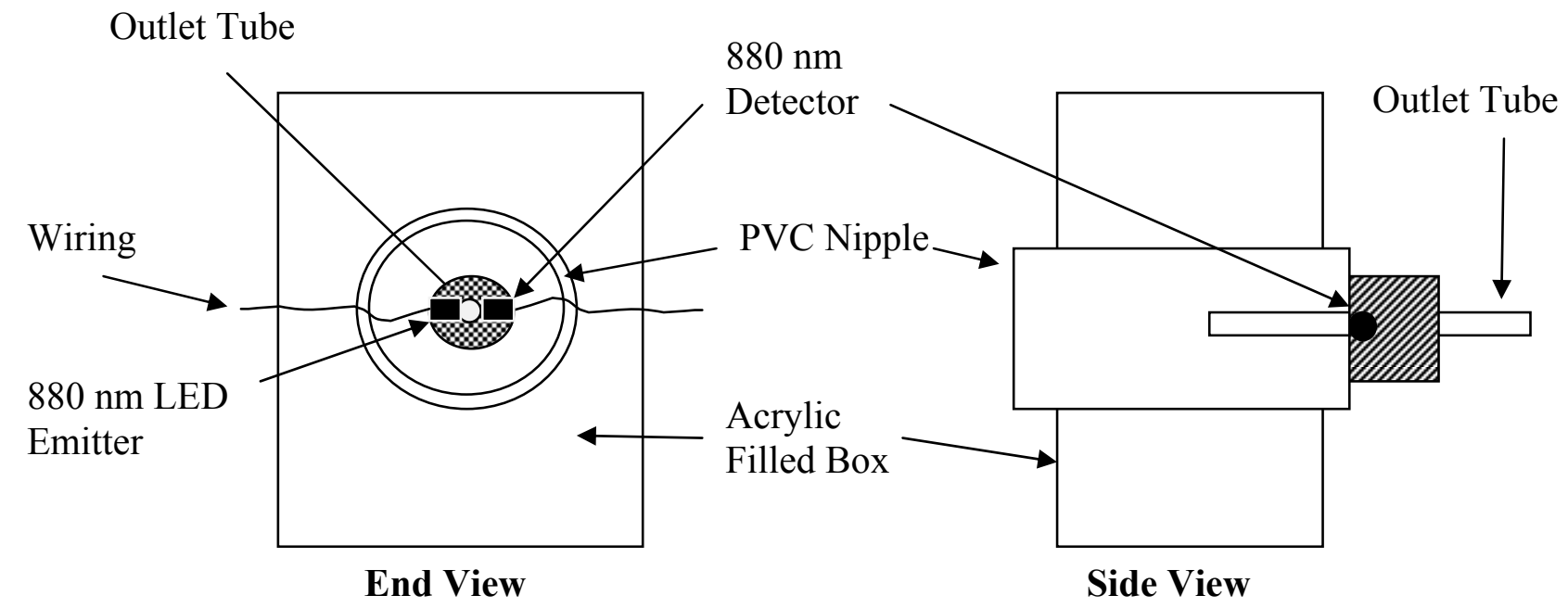


Soil Test No. 3

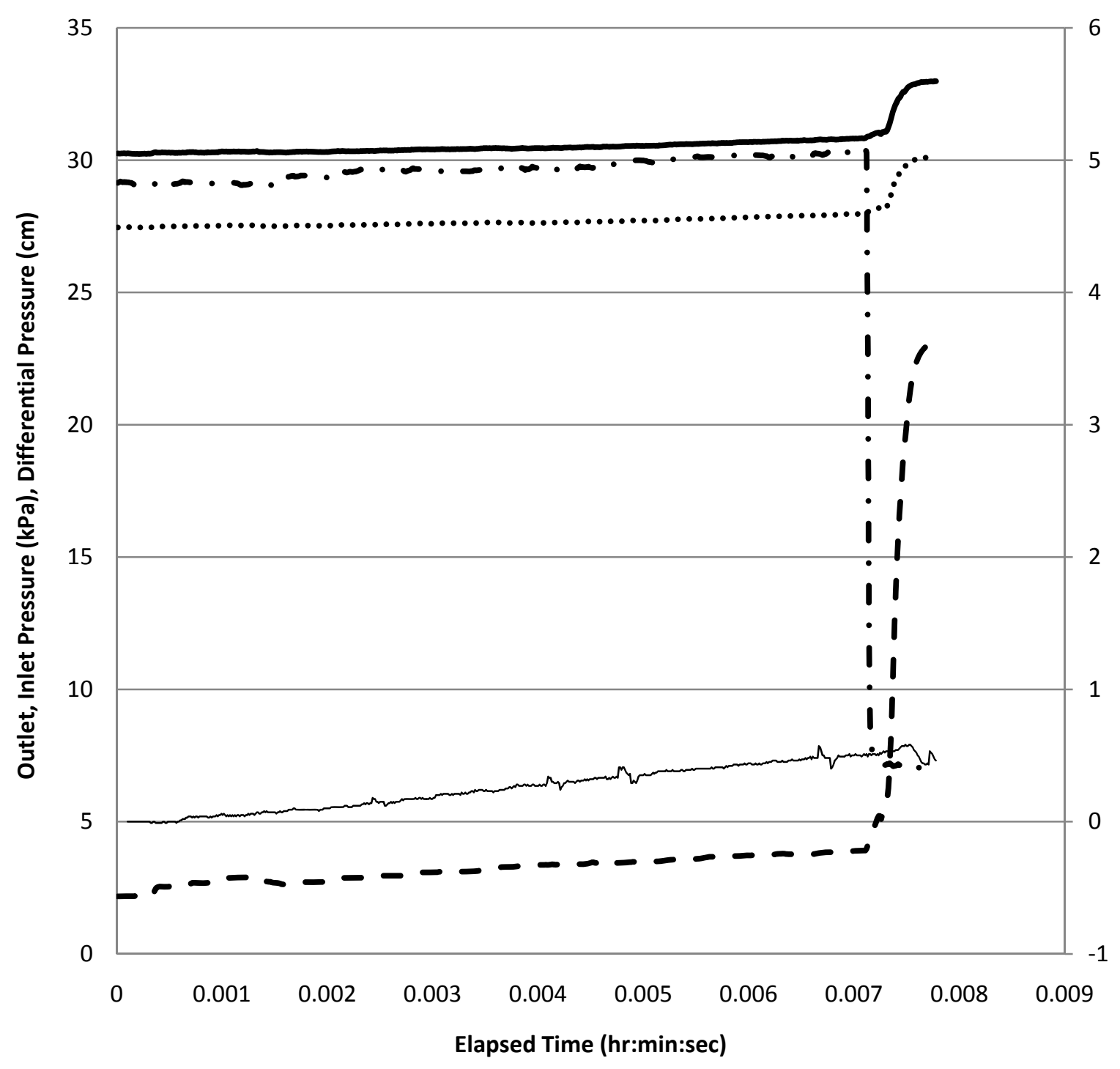

Soil QS

...... Outlet Pressure (kPa)

_ Inlet Pressure (kPa)

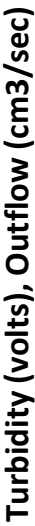

- - Differential Pressure

- - Turbidity (volts)

10 per. Mov. Avg. (Outflow $(\mathrm{cm} 3 / \mathrm{sec}))$ 


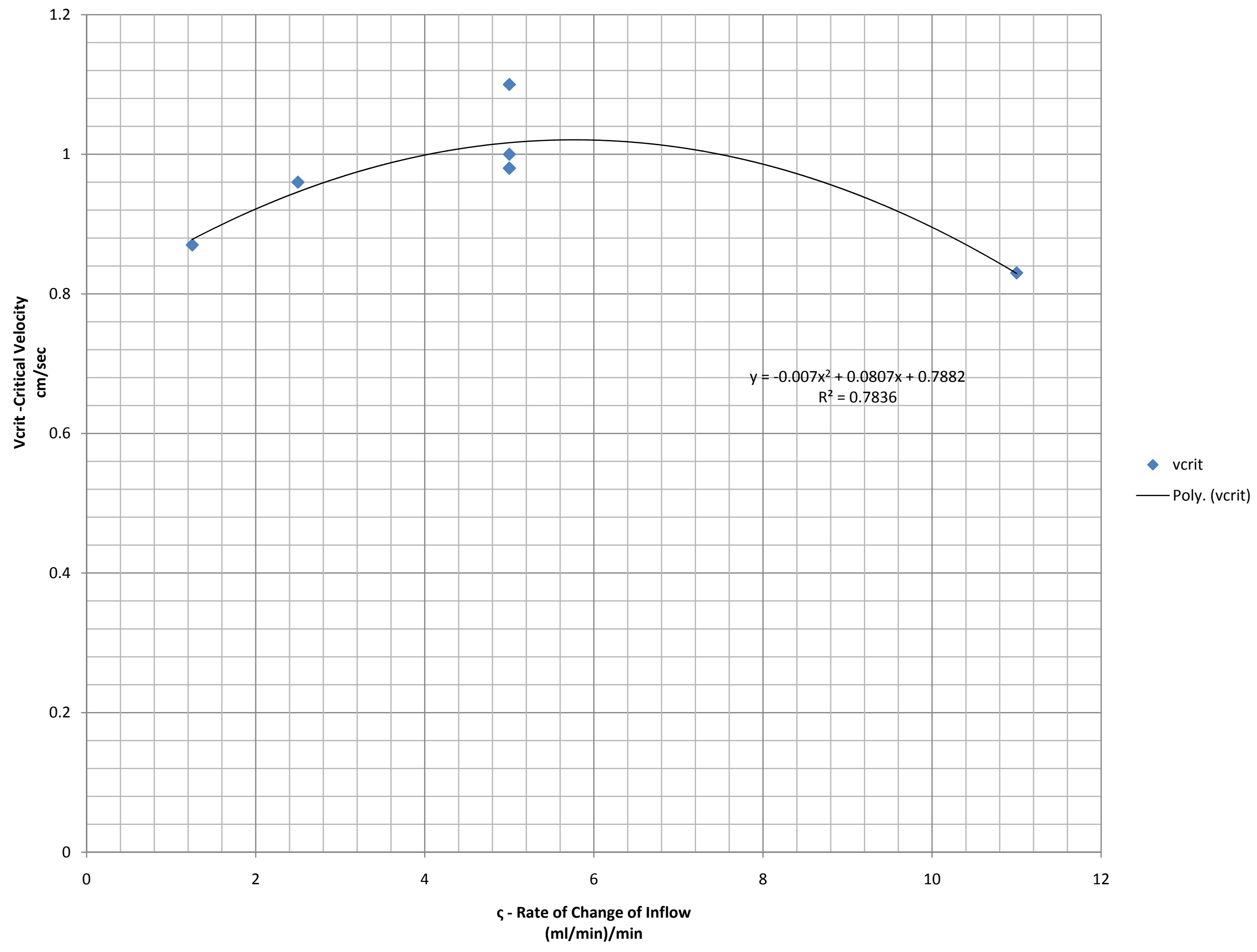




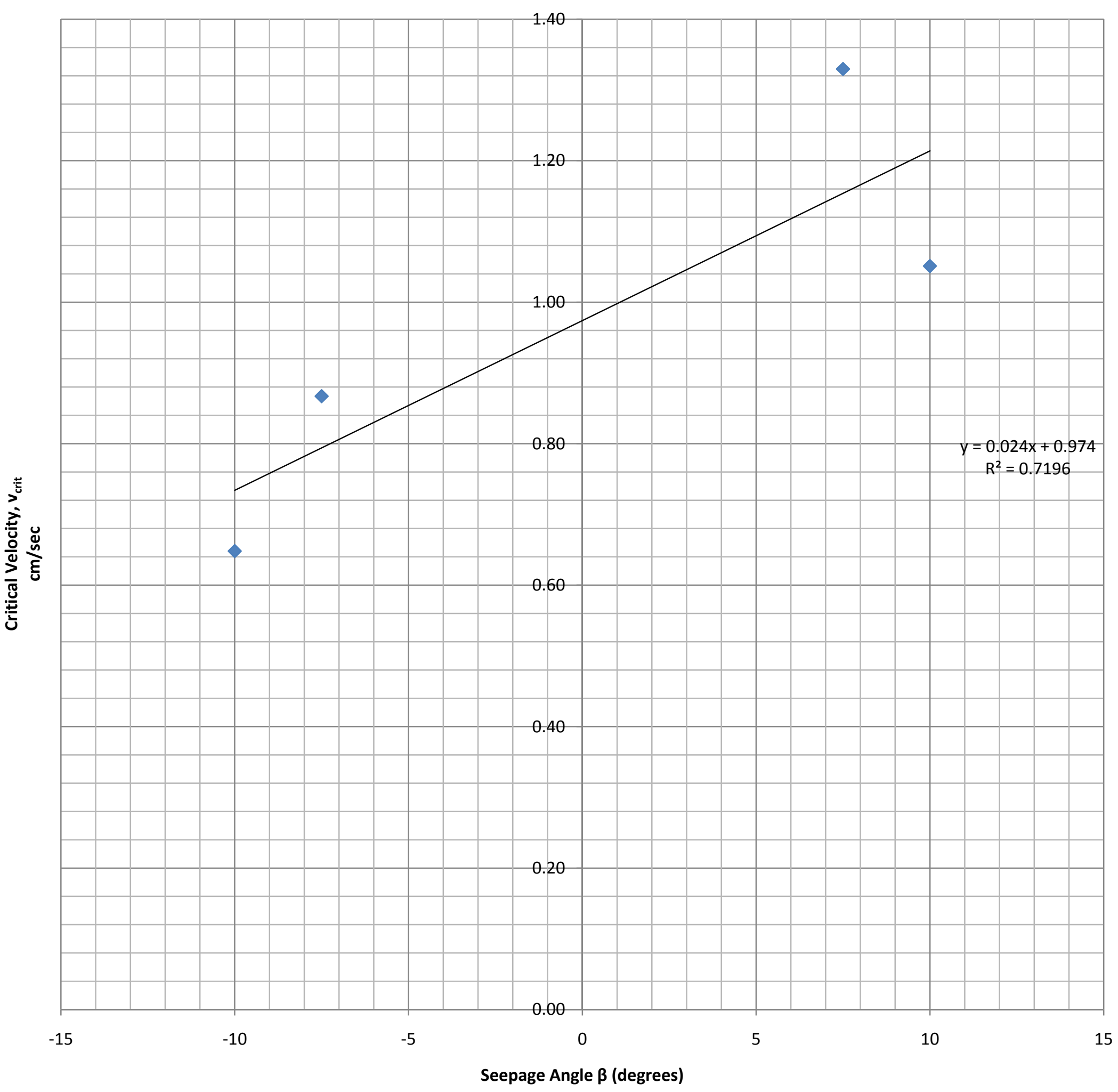

- Seepage Angle vs vcrit

_ Linear (Seepage Angle vs vcrit) 